\title{
LITERACY-BASED PPKN POCKET BOOK DEVELOPMENT TO IMPROVE STUDENT LEARNING OUTCOMES OF CLASS IV SDN 067243 MEDAN SELAYANG DISTRICT, YEAR 2020/2021
}

\author{
Ifran Fredy Tarigan ${ }^{1}$ \\ State University of Medan, Indonesia \\ E-mail : Ifrantarigan11@gmail.com
}

Reh Bungana Br Perangin-Angin ${ }^{2}$

State University of Medan, Indonesia

E-mail : rehbungana@unimed.ac.id

Daulat Saragi ${ }^{3}$

State University of Medan, Indonesia

E-mail : daulat.saragi@gmail.com

\begin{abstract}
This research is a type of research development (Research and Development) which aims to determine how the development of a Literacy-based PPKn pocket book, how the feasibility and effectiveness of the Literacy-based PPKn pocket book. The method used to analyze the data is a qualitative descriptive technique which is expressed in the distribution of scores and categories of the rating scale. This development research produces products that meet the eligibility requirements after validation by expert validators. material validation was declared very feasible with a percentage of $89.77 \%$. For linguists it is stated very feasible with a percentage of $88 \%$. and design experts are declared fit for use with a percentage of $80.76 \%$. In this study, feasibility was also obtained from student response questionnaires after students used and ate the products that had been developed. The results of the student response questionnaire to the development of the Literacy-based PPKn pocket book were also said to be feasible with a percentage of $76.19 \%$. The effectiveness of the product can be seen from the $\mathrm{N}$-Gain value. From the $\mathrm{N}$-Gain value of the experimental class reaching 0.48 , it was stated that the effectiveness of the pocket book was in the
\end{abstract}


Medium category. It is different from the control class which is categorized as low effectiveness with a score of 0.26. Furthermore, the researcher tested the research hypothesis, whether the hypothesis was acceptable or not using the $t$ test with the help of the SPSS program. In the output of the paired sample test with SPSS version 17, the Sig (2-tailed) value of $0,000<0.05$ was obtained, so according to the basis for decision making in the paired sample test it can be concluded that $\mathrm{Ho}$ is rejected and $\mathrm{Ha}$ is accepted, it can be concluded that the development of a pocket book Literacy-based PPKn is feasible and effective to use in grade IV SDN 067243 Medan Selayang District Year 2020/2021

Keywords: Pocket Book, Literacy, Learning Outcomes

\section{A. Introduction}

Technology and information allow one to gain knowledge from various media. Now, electronic books can be accessed anytime, anywhere, and in any situation. However, reading is not a priority in this country. According to Albert Bandura, a psychology expert in the field of social learning theory, adolescents who display positive work behaviors certainly cannot be separated from the learning process, such as observing or observing the behavior of those around them. Bandura (QN Laila 2015:26) says: "There is a close relationship between students and their environment. Learning occurs in the relationship between three parties, namely the environment, behavior and personal factors.

The results of Rohman's research (2017:173) explain that the main obstacle in maximizing language skills and fostering interest in reading in children is the lack of reading sources that are in accordance with the child's world so that they prefer to spend time with other entertainment which is indeed more numerous. Apart from the lack of reading sources, one of the factors causing the low reading interest of students, especially in elementary schools (SD) is that students are not stimulated to read and 
seek information. The education system applied in schools also has an impact on reading interest. In general, the teaching and learning process in Indonesia uses a very minimal explanation model that directs students to get information by reading books. This is why students become passive and just accept it without trying on their own to find out more. This condition has been corrected in the new curriculum, namely the 2013 curriculum, but of course it takes time to get the results as expected.

The presence of learning media in teaching and learning activities is very helpful in student literacy activities. Learning media are all forms of communication tools that can be used to convey information from sources or teachers to students which aims to stimulate them to participate in learning activities as a whole, can also be used to convey certain parts in learning activities (Kustandi and Sutjipto, 2011:5).

Based on preliminary research through direct observation and interviews on January 30, 2019 conducted with the fourth grade homeroom teacher, Mrs. Nurlince Sinaga, S.Pd at SD 067243, Medan Selayang Subdistrict, it is known that in Civics learning students are less focused on learning. This is indicated by the presence of some students who still do not pay attention to the teacher's explanation in the learning process. Even at home, there are still many students who have not studied well.

Some students do not do the homework that has been given by the teacher. Students feel lazy and bored in studying Civics material which has a wide scope. The textbooks owned by students are also limited. The lack of textbooks or reference books owned by students as complementary learning books, causes a lack of insight into the knowledge possessed by students. Civics learning with broad material, we need a way so that students can understand the Civics material easily. 
Therefore we need an interesting, innovative, concise, easy-to-learn learning media that can be used by students to add references, insight into understanding Civics material independently and easily. Through the initial observation sheet about classroom learning, it appears that students are less active in literacy activities such as reading or listening in class. Literacy activities are also limited to reading and writing so that student activities are less effective and meaningful even though there are many literacy activities that can be done by students that will not make them bored in studying Civics lessons.

Therefore we need an interesting, innovative, concise, easy-to-learn learning media that can be used by students to add references, insight into understanding Civics material independently and easily. Through the initial observation sheet about classroom learning, it appears that students are less active in literacy activities such as reading or listening in class. Literacy activities are also limited to reading and writing so that student activities are less effective and meaningful even though there are many literacy activities that can be done by students that will not make them bored in studying Civics lessons.Therefore we need an interesting, innovative, concise, easy-to-learn learning media that can be used by students to add references, insight into understanding Civics material independently and easily.

\section{B. Method}

\section{Research Location and Time}

This research was conducted at SD Negeri 067243 which is located at Jalan Bunga Sedap Malam XI, Medan Selayang District. This research was conducted in the even semester of the 2020/2021 Academic Year. The implementation of this research was carried out in March 2021. 


\section{Research subject}

The subjects of this research are: (1) students of SD Negeri 067243 Kec. Intermediate field class IV-a and IV-b as the subject of field trials; and (2) three experts, each of which has criteria: material expert, linguist and media expert.

\section{Development style}

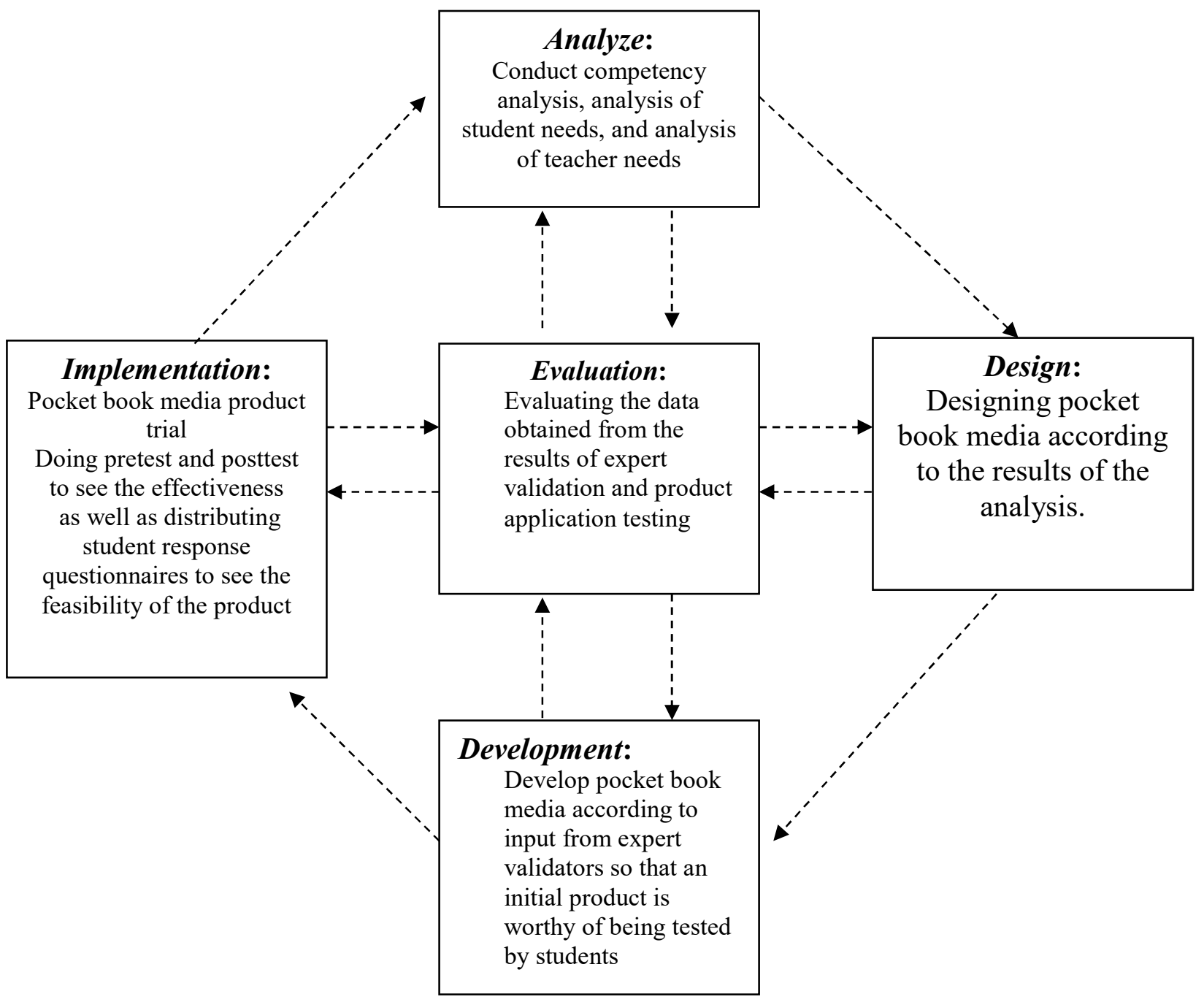

Figure 1. ADDIE Research and Development Model 


\section{Development Procedure}

The procedure for developing pocket book media for literacy activities is carried out through five stages (ADDIE), namely: Analyze (Analysis Stage), Design (Design Stage), Development (Development Stage), Implementation (Phase of Implementation) and Evaluation (Evaluation Stage).

\section{Data Collection Techniques}

Data collection techniques are methods and instruments used in collecting research data. Research instruments are tools or facilities used by researchers in collecting data so that their work is easier and the results are better, in the sense of being more accurate, complete, and systematic so that they are easier to process. The instruments used in this study were expert validation questionnaires, student response questionnaires and learning outcomes tests.

\section{Finding and Discussion}

\section{Results}

\section{Development of Pocket Book Media}

The purpose of this research is to produce learning tools in the form of a good pocket book in accordance with the sub-themes of ethnic and religious diversity in my country. To achieve this goal, development research is carried out first. The steps taken to obtain the learning tools in this study were the ADDIE development model. The ADDIE model steps include aspects of Analyze (analysis), Design (design), Development (development), Implementation (application), and Evaluation (assessment). 


\section{Description of the analysis stage (analyze)}

The activities at this stage are the analysis of student characteristics and curriculum analysis, which are then used as the basis for the formulation of the learning tools developed. The analysis phase in this research includes curriculum analysis and analysis of student characteristics. At this stage the researcher analyzes the learning material by identifying the main material to be taught, selecting the relevant material and rearranging it systematically.

Based on the identification of the material, 3 components of the main material are obtained which will be developed in 2 lessons using the developed pocket book product. If the textbooks that are commonly used are not able to improve learning outcomes and understanding of the material by students, it is hoped that the use of this pocket book can overcome that problem.

\section{Stages of design (design)}

After conducting the analysis process, the next step is to design learning tools. The initial product of the learning device is in the form of a learning pocket book. At this stage the researcher developed a pocket book in grade IV on the theme of 7 sub-themes 1 of ethnic and religious diversity. The researcher chose to develop a pocket book for the fourth grade of SDN 067243, Medan Selayang Subdistrict because the teacher at the school had never used and developed a pocket book to improve student skills. The stages of designing a pocket book outline include the following: 
Table 1. Pocket Book Design

No Format
Pocket book cover
1. Foreword
General Instructions:
Praise and gratitude the authors pray to the
presence of God Almighty who has bestowed His
grace and gifts so that the author can compile a
pocket book as a learning medium for literacy
activities. This pocket book is designed to increase
students' understanding of the subject matter of
the Beauty of Diversity in my Country in the
subject of Citizenship Education. It is hoped that
this book can provide student learning outcomes
so that they can understand the Civics material
more optimally.

Field,

Author

Ifran Fredy Tarigan 


\section{Table of contents}

\section{TABLE OF CONTENTS}

Preface................................................. i

Table of contents........................................... ii

Core Competencies ............................... iii

Basic competencies .......................................... iii

Indicator ................................................... iv

CHAPTER I. Tribes in Indonesia ...................... 1

CHAPTER II. Tribes in North Sumatra .............. 9

CHAPTER III. Religious Diversity in Indonesia .. 22

Reflection

Bibliography

Achievement Indicator

C. . INDICATOR

1. Get to know ethnic groups in the Republic of Indonesia.

2. Getting to know the tribes in North Sumatra

3. Understand the relationship between the many ethnic groups and regional conditions in Indonesia, especially North Sumatra.

4. Understanding and Knowing Religion in Indonesia 


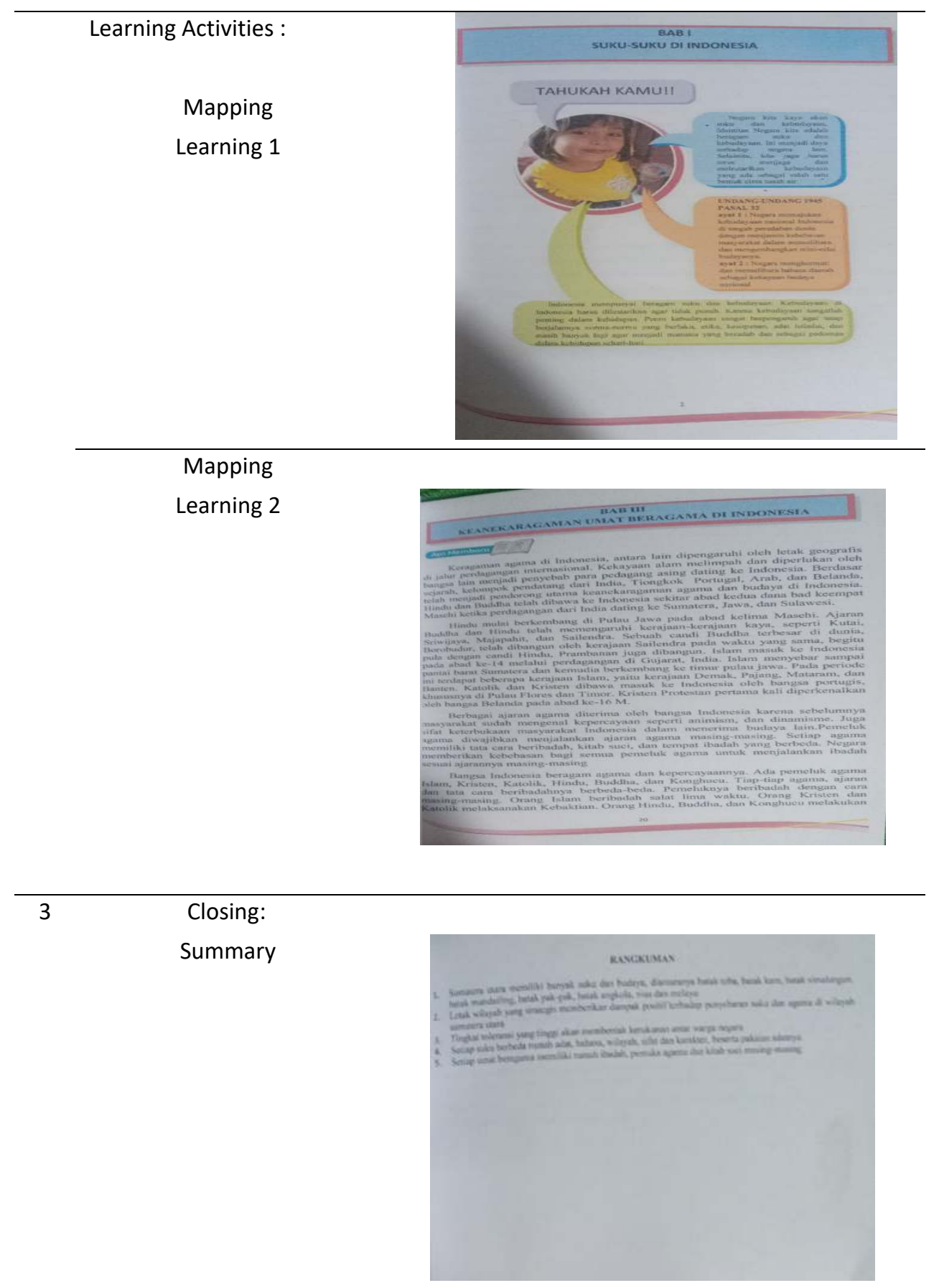




Bibliography 4. BIOGRAPHY
Dasim, Budimansyah. (2010). Strengthening
Citizenship Education to Build National
Character. Bandung: Widya Aksara Press
Masan, M. 2009. Learning Guide and Evaluation of
Citizenship Education for Elementary and MI
Grade 4. Jakarta: PT. Grasindo.
Ministry of Education and Culture of the Republic
of Indonesia. 2017. Integrated Thematic
Teacher's Book 2013 Curriculum for SD/MI
Class V. Jakarta: Center for Curriculum and
Books, Balitbang, Ministry of Education and
Culture
Kusumawati, Heny 2017. Thematic Book on
Integrated Curriculum 2013 Theme 7: The
Beauty of Diversity in My Country Books for
SD/MI Class IV students. Jakarta: Ministry of
Education and Cultur

\section{Stages of development (development)}

Several aspects used to be used as material for product revision include several components, namely: the feasibility of expert validators (material experts, linguists, and design experts), then a student response questionnaire will also be seen to determine the feasibility of the product whether the product is good and feasible in terms of assessment of students after they have finished using and studying the pocket book. The media feasibility process is carried out by validating the product by material experts, linguists and design experts. As well as student response questionnaires. Each validation result is classified in the form of a percentage (Sugiono, 2011:118). 


\section{Stages of implementation (implementation)}

At this implementation stage, the product in the form of a pocket book has been designed and validated by the expert validation team. After the expert validation team declared it was valid, it would then be tested on students. The product trial was carried out in class IV SDN 067243, Medan Selayang District with a total of 15 students in the control and experimental classes. at the implementation stage, product trials are carried out when the product has been completed, product trials can determine whether the product developed is effective. Field trials were conducted using an experimental model, the experimental model was chosen to compare the effectiveness of teaching with teaching materials in the form of teaching materials and teaching conventionally. Experiments can be done by comparing with the situation before and after using teaching materials (before-after) or by comparing with groups that do not use teaching materials or with conventional methods. In this case there is an experimental group and a control group.

\section{Stages of evaluation (evaluation)}

The evaluation stage is the final stage in this research. The evaluation was carried out on the results of the product feasibility test and the effectiveness test of learning tools in the form of a guided pocket book in the sub-theme of ethnic and religious diversity. The evaluation results are used as the final conclusion regarding the results of the product analysis developed, and serve as a benchmark for the success of researchers in answering questions in this study. 


\section{Discussion}

\section{Pocket Book Media Development}

The textbooks or textbooks used so far are less effective books for all students, so they are not there are variations that are adapted to their real life (contextual) so that children become bored. According to Florence Y. Odera (2011:32) "Media also integrates students in the learning experience, explaining and describing lesson content and performance skills in addition to providing opportunities for self-analysis of individual performance and behavior". So that researchers develop alearning tools in the form of Guided pocket book for Class IV students at SDN 067243, Medan Selayang Subdistrict

Learning device is a device used in the teaching and learning process. Therefore, every teacher in the education unit is obliged to develop learning tools that take place interactively, inspiring, fun, motivating students to participate actively (Devi, 2009: 1-5). Learning tools needed in managing the teaching and learning process can be in the form of: syllabus, lesson plan (RPP), student activity sheet (LKS), and pocket book. Pocket books are one of the learning media that can be used to support teaching and learning activities. A pocket book is a learning tool or facility that contains materials, methods,

\section{The Eligibility of Pocket Books on Student Learning Outcomes}

To find out the feasibility of pocket books, validity tests were carried out by material experts, linguists and design experts, as well as looking at the assessment of student response questionnaires. Where each expert gives an assessment of each indicator contained in the questionnaire sheet. The product deserves to be tested for what spaciousness if the expert team has validated the product with a valid category with revision or without revision. From the average percentage 
of the results of the three expert validations, the Pocket Book media product for student literacy activities is categorized as valid or suitable for use for fourth grade students with an average score of $83.87 \%$, very valid and very feasible. Likewise with the assessment of the student response questionnaire sheet with an average percentage score of $76 \%$ with a valid category or suitable for use for fourth grade students.

From the discussion above, it can be concluded that the development of a learning device in the form of a pocket book must meet the eligibility criteria so that the product developed can be implemented for fourth grade elementary school students. Especially for class IV SDN 067243 Medan Selayang District

\section{The Effectiveness of Pocket Books on Student Learning Outcomes}

The effectiveness of the Pocket Book media was measured using an analysis of the learning outcomes test before and after using the media, the data from the learning outcomes test given to students amounted to 15 multiple choice questions consisting of $a, b, c, d$. From the results of the average pretest and posttest in the table above, it can be calculated that the N-Gain for the Control class is equal to and the experimental class is equal to 0,26 (low) 0,48 (medium)

Judging from the data above the value of $\mathrm{N}$ - Experimental class gain reached 0.48 . It can be said that the effectiveness of the pocket books for Class IV students at SDN 067243, Medan Selayang District, is categorized as Effective. In contrast to the control class which is in low category by not using a pocket book. The use of learning tools, among others, can save learning time, save costs, create space for teaching consistency, mastery of learning, increase retention, increase safety, increase motivation, increase student/student access to learning is not limited to the presence of teachers (Nkweke et al, 2012). 
From the results of research on the effectiveness of this study, there are several similarities with previous research including Ali Abdi's research (2014) This study aims to determine the effectiveness of learning methods and achievement tests about science consisting of 30 items given as pre-test and post-test for good students. in the experimental and control groups. For statistical analysis, Analysis of Covariance (ANCOVA) was used. The results showed that students who were instructed through inquiry-based learning achieved higher scores than those who were instructed through traditional methods. The results of this study indicate that pocket books can improve student learning outcomes. And also research by Erna Novitasari (2016),

From the results obtained, there are similarities with previous research, namely, the results of research conducted by Sulistyani Nurul Hidayati Dyah et al (2013) showed that there was a significant difference between the use of pocket books and without pocket books on student learning outcomes. These results were also obtained by researchers in the research that has been done. After knowing that the data is homogeneous, the researcher can test the hypothesis by using the t-test.

From the discussion above, it can be concluded that the development of a learning device in the form of a guided pocket book for students must meet the criteria for effectiveness.

\section{Conclusion}

Based on the formulation, objectives, results and discussion of research and development on pocket book learning tools, sub-theme 7 sub-theme 1 "ethnic and religious diversity" Class IV SDN 067243 Medan Selayang Subdistrict which was stated earlier, it can be concluded as follows: 
a. The result of this research is a media product of Learning Pocket Book Theme 7 Sub-theme 1 in grade IV SDN 067243 Medan Selayang District. This learning product is feasible and valid for use by Class IV students of SD Negeri 067243 through assessment, revision, and validation from several experts. This conclusion is drawn based on the results of the analysis of experts consisting of material aspects in this category which is considered very valid with a percentage of $89.77 \%$. The linguist test is considered very valid with a percentage of $88 \%$. The learning design expert test obtained a valid value with a percentage of $80.76 \%$. Student response questionnaire for guided learning tools Learning Pocket Book Theme 7 Sub-theme 1 "ethnic and religious diversity" grade IV SDN 067243 Medan Selayang District obtained an average of $76.19 \%$ with valid/feasible criteria.

b. The results of the pretest control class students achieved an average score of 53 . While the posttest results for the control class reached 67 , for the experimental class it reached an average of 50 and after using a pocket book it reached an average of 74 . To see the effectiveness using the $\mathrm{N}$-gain formula with a value of $\mathrm{N}$-Gain reaches Control Class and Experiment Class which have different effectiveness. Where the experimental class has a higher effectiveness 0,26 (low) 0,48 (medium)

c. At the output of the paired sample test with SPSS version 17, the Sig (2-tailed) value is 0.000 . The value of Sig (2-tailed) is $0.000<0.05$, so according to the basis of decision making in the paired sample test, it can be concluded that $\mathrm{Ho}$ is rejected and $\mathrm{Ha}$ is accepted, which means that there is a significant difference between the learning outcomes of fourth grade students at SD Negeri 067243 Merdan Selayang. before using pocket book media and after using pocket book media. 


\section{Bibliography}

Amy Benjamin \& Michael Hugelmayer. 2013. Big Skills For The Common Core Literacy Strategies For The 6-12 Classroom. New York London. Routledge

David L. Grossman, Wing On Lee, dan Kerry J. Kennedy (eds.). (2008). Citizenship Curriculum in Asia and The Pacific. Hong Kong: CERC The University Hong Kong and Springer. diakses pada tanggal 12 Mei 2019.

Elvira Firdausi Nuzula dan Abdur Rahman As'ari, "Pengembangan Buku Saku VolumeKubus, Balok, dan Limas sebagai Media Pembelajaran untuk Siswa SMP," SKRIPSI JurusanMatematikaFakultas MIPA UM, 2013. Diakses tanggal 21/10/2019.

Kustandi, C dan Sutjipto, B. (2011). Media Pembelajaran Manual dan Digital. Bogor: Ghalia Indonesia.

Qumruin Nurul Laila. 2015. Pemikiran Pendidikan Moral Albert Bandura. www.jurnal.stitnualhikmah.ac.id/index.php/modelling/article/do wnload/45/45.diakses tanggal 03/03/2018.

Rohman, Syaifur. 2017. Membangun Budaya Membaca Pada Anak Melalui Program Kegiatan Literasi Sekolah. TERAMPIL Jurnal Pendidikan dan Pembelajaran Dasar volume 4 No 1 Juni 2017. 